$\begin{aligned} & \text { Fearless food } \\ & \text { Transgenic crops may } \\ & \text { carry minimal health } \\ & \text { risk, report concludes } \\ & \text { p358 }\end{aligned}$
p360

\title{
Physics poised for sizeable gains in energy department's wish-list
}

\section{Geoff Brumfiel, Washington}

The US Department of Energy (DOE) is developing an ambitious plan to build a new generation of large scientific facilities during the next two decades.

Over the past six months, the head of the DOE's Office of Science, Ray Orbach, has been collecting a list of proposed experiments and facilities that would range in cost from tens of millions to billions of dollars. The list now includes some 50 projects, mostly in the physical sciences, and supporters say it could provide direction for the science office for years to come.

But before the list can be prioritized and released, it must win the support of the energy department's highest officials and pass muster with the president's budget office, which is attempting to hold down government spending in the face of record budget deficits.

Researchers at the laboratories involved are eager to learn how their projects are faring in the prioritization process, but Orbach has declined repeated requests to discuss its progress. The facilities plan is currently undergoing a stringent review within the upper levels of the department, according to those close to the process.

The DOE is the largest supporter of

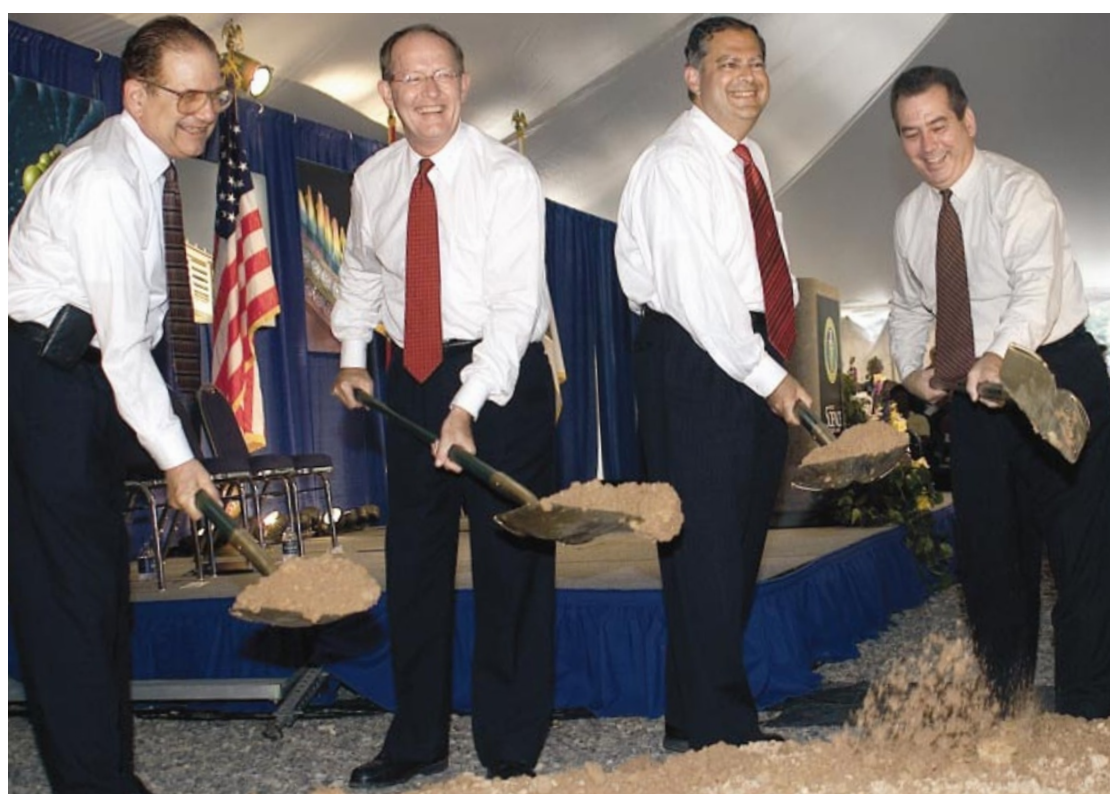

Digging deep: (from left) Ray Orbach, Senator Lamar Alexander, Spencer Abraham and William Madia, director of Oak Ridge National Laboratory, break ground for the lab's nanotechnology facility.

physics in the United States, and Orbach's office spends more than $\$ 3$ billion a year. Most of that goes on a network of laboratories that house many of the nation's largest scientific facilities, such as the Tevatron accelerator at Fermilab near Chicago, which discovered the top quark in 1995 . The department last outlined a comprehensive facilities

\section{US observation initiative calls for fresh view of Earth}

\section{Tony Reichhardt, Washington}

The United States is convening an international summit in Washington DC next week to tout plans to consolidate scientific observations of the Earth - and to help repair its reputation as a foot-dragger in global climate change.

Attendees at the meeting on 31 July will be asked to sign a declaration calling for increased sharing of data from instruments on the ground, in the air and in space. The summit will be followed by meetings of a working group to begin developing a ten-year plan for an integrated Earth-observation system, which would help to standardize data from sensors operated by different nations, as well as identify gaps in those data.

Participants will include US secretary of state Colin Powell and half-a-dozen other US cabinet members, along with ministers from most leading industrial nations and representatives of the World Bank and the World Meteorological Organization.

Ray Williamson, an expert on Earthobservation policy at George Washington University in Washington DC, says that some contentious issues could surface at the meeting - such as who would set the requirements for an integrated system. Europeans already have programmes with similar goals, he says. They may also be wary of any US effort to dominate the field.

The United States also faces scepticism from those who suspect that its enthusiasm for collecting more data on climate change is simply "a way of putting off making some hard decisions" on greenhouse gases, Williamson says.

But Anthony Janetos, director of the global-change programme at the Heinz Center, a think-tank in Washington, says that given the difficulties of coordinating large observation programmes, "the reaffirmation of a US commitment to an integrated system is enormously important". 
plan 20 years ago, in an exercise that led to the construction of a string of projects. Although it still starts up some mediumsized facilities - such as the nanotechnology facility for which Orbach and his boss, energy secretary Spencer Abraham, broke ground last week at Oak Ridge National Laboratory in Tennessee - it has no overall plan for larger ones.

Last December, Orbach sent out a letter to advisory groups asking them to suggest new facilities that the directorate could build. "Creating these facilities for the benefit of science is at the core of our mission," the letter read.

The response was enthusiastic, according to University of Oregon chemist Geraldine Richmond, who chairs the department's basic energy sciences advisory committee. Among the facilities recommended by Richmond's committee is a series of new light sources to probe materials and molecules.

At the top of the nuclear physicists' list is the Rare Isotope Accelerator, which would carry out experiments on highly unstable nuclei in an effort to reproduce nuclear reactions inside stars and supernova explosions. Planning for the machine has been hampered by budget problems and uncertainty over when it will be built, says Richard Casten, a nuclear physicist at Yale University who heads the nuclear science advisory group. "My feeling is that maybe what Orbach's doing can change that," he says.

At a cost of about $\$ 800$ million, the isotope accelerator would be one of the more ambitious projects under consideration, but it is by no means the most expensive. Also being considered are a \$5-billion experimental fusion reactor known as ITER, and a \$6-billion linear collider for high-energy physics.

Martha Krebs, who served in Orbach's position under the Clinton administration from 1993 to 1999 and is now a consultant in Los Angeles, says: "Putting out a preferred list will be very difficult to do." She tried to draw up a similar list of facilities during her tenure, but ran into difficulties with the energy secretary and the White House Office of Management and Budget, whom she says wouldn't approve a plan that called for billions of dollars in additional spending.

At that time, support in Congress was weak for both the energy department and its science office - but that may be changing, Krebs says. The House of Representatives has just approved a $6.5 \%$ increase for DOE science (see page 561), and congressional staff members who oversee the department are eager to see what facilities plan the department can come up with. "I'm dying to see how they're going to handle this," says one.

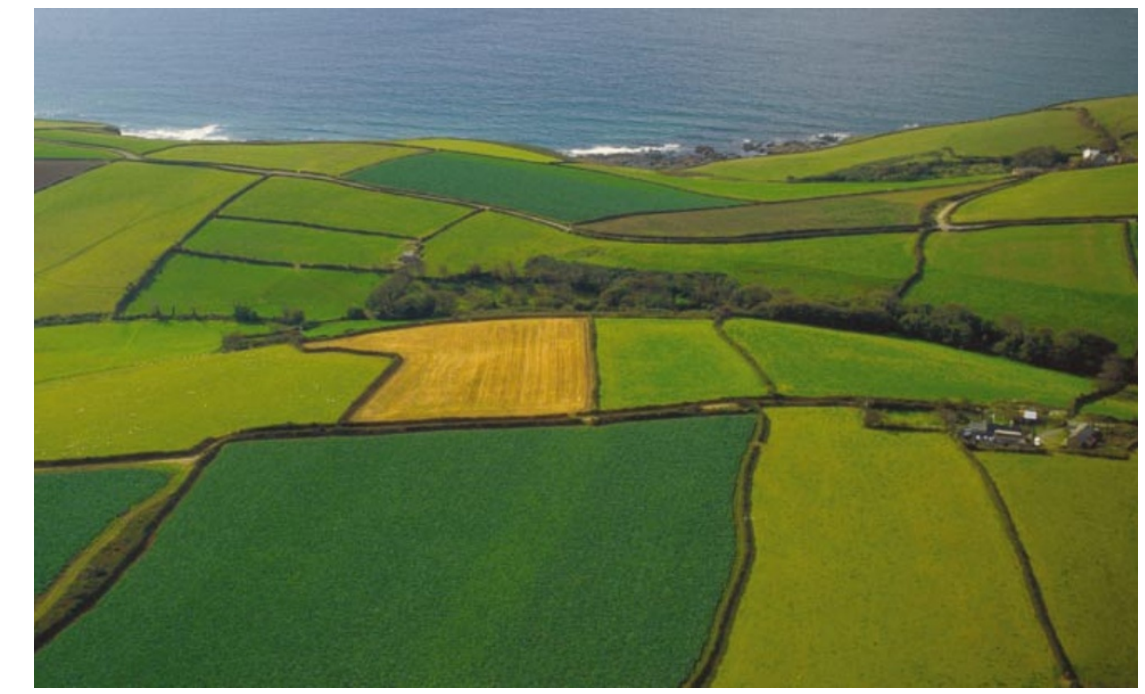

Green issue: scientists say that transgenic crops' effects on farmland are their most pressing concern.

\section{UK experts map out route to licensing transgenic crops}

\section{Jim Giles, London}

There are no human-health grounds for holding up the planting of transgenic crops in Britain, an expert panel has told the UK government.

But the panel said that the crops could have adverse environmental impacts, and should only be grown after case-by-case assessments of the risks. Its findings, released on 21 July, are expected to influence the government's decision on whether to license some transgenic crops for commercial planting later this year.

The panel was chaired by the government's chief scientific adviser, David King. Its work is part of a three-pronged assessment of transgenic crops by the UK government, which has also included a report issued on 11 July on the crops' economic impact, and a public consultation involving 500 meetings held around the country.

The process is being watched closely because British consumers' rejection of the technology is influencing its adoption in many other countries. "This will be influential internationally," says plant scientist Mark Tester of the University of Cambridge.

But it remains unclear whether the panel's tentative green light for the technology will be enough to open the door to British cultivation of transgenic crops any time soon. Prime Minister Tony Blair has advocated the technology, but his unpopularity in the aftermath of the Iraq war may reduce the likelihood that he can persuade consumers, or environmental protesters, to accept it.

The panel, which included representatives from the biotechnology industry and conservation organizations as well as university scientists, struggled to reach a consensus, its members say. On the way, they digested more than 600 papers, lost a panel member, and survived a series of last-minute revisions that threatened to scupper the entire project.

"It's a minor miracle that the report got put together," says panel member Mike Gasson, head of food-safety science at the Institute of Food Research in Norwich. Carlo Leifert, an expert in organic agriculture at the University of Newcastle-upon-Tyne, quit the panel last month.

The panel's report makes some concessions to critics of transgenic food, including, for example, the observation that allergens produced by transgenes may not be spotted during regulatory screening, and may only emerge once a crop is widely grown. But another fear often raised by environmental groups - that transgenic crops could give rise to herbicide-resistant 'superweeds' was played down in the report.

Members were also split on whether extensive growth and consumption of such crops in the United States constitute evidence that they are safe to eat. The panel eventually agreed that the available research shows risks to human health to be "very low".

A large-scale study of the impact of herbicide-tolerant transgenic crops on biodiversity, conducted by a team of UK-based scientists (see Nature 412, 760-763; 2001), is currently undergoing peer review, and the panel said it was reluctant to draw conclusions about environmental risks in the meantime. The panel said, however, that "the most important issue is [the crops'] potential effect on farmland and wildlife", and pledged to update its report after the biodiversity study is published.

www.gmsciencedebate.org.uk 